Dialectologia 17 (2016), 123-150.

ISSN: 2013-2247

Received 15 November 2014.

Accepted 15 March 2015.

\title{
RUSSIAN IN BESERMAN ORAL DISCOURSE: CODE-MIXING AND BORROWING ${ }^{1}$
}

\author{
Maria USACHEVA \& Olga BIRYUK \\ Moscow State University* \\ mashastroeva@gmail.com/biryuk.olga@gmail.com
}

Abstract

The paper is devoted to the influence which Russian as a dominant language exerts on Beserman dialect of Udmurt. Analysis is based on a corpus of dialogues recorded and transcribed in Shamardan (a Beserman village in Udmurtia, Russian Federation). It is shown that Russian influence in forms of codemixing and borrowing can be seen at all language levels: phonetics, inflectional morphology, vocabulary, syntax, discourse. It is stated that the changes could result in a mixed idiom, but the dialect is likely to die because it is not passed to next generations anymore.

\section{Keywords}

code-mixing, borrowing, Beserman, Russian, Udmurt

\section{EL RUSO EN EL DISCURSO ORAL DEL BESERMAN: \\ CAMBIO DE CÓDIGO Y PRÉSTAMOS}

\section{Resumen}

El artículo estudia la influencia que el ruso como lengua dominante ejerce sobre el Beserman, dialecto del udmurto. El análisis se basa en un corpus de diálogos grabados y transcritos en Shamardan (un pueblo

\footnotetext{
${ }^{1}$ The data the current work is based on were gathered during fieldwork financed by RFH, grant № 16-2417003 "Integral analysis of noun phrases in Finno-Ugric languages: support of reference and encoding information structure of the utterance". The analytical work was supported by RFBR, grant № 16-06-00536 "Syntax-semantic interface in Uralic and Altaic languages".

* 119991, Lomonosov Moscow State University, Leninskiye gory, GSP-1, Moscow, Russian Federation.
} 
dónde se habla Beserman, en Udmurtia, Federación Rusa). Se muestra que la influencia rusa en forma de cambio de código y de préstamo se puede observar en todos los niveles de la lengua: la fonética, la morfología flexiva, el vocabulario, la sintaxis y el discurso. Se afirma que los cambios experimentados podrían dar lugar a una lengua mixta, aunque el dialecto es probable que muera ya que no se transmite de generación en generación.

\section{Palabras clave}

cambio de código, préstamos, Beserman, ruso, udmurto

\section{Introduction}

This article concerns the Beserman dialect of Udmurt. Besermans is a relatively small (according to the All-Russian population census, there are 2201 people identifying themselves as Beserman) ethnic group occupying the basin of Cheptsa river and the Kirov region of the Russian Federation. Besermans consider themselves to be a nationality different from Udmurts and to speak a unique language. But in the scientific literature the Beserman idiom is considered to be a dialect of Udmurt language which is characterized by an unusual combination of specifically Beserman language phenomena (concentrated in vocabulary and phonetics) with certain traits of northern and southern Udmurt dialects (mostly morphological and phonetical) (see Teplyashina 1970, Kelmakov 1998, Ljukina 2008). More concrete, R. Idrisov (2013) demonstrates that among 110 units of words denoting basic concepts (100 of them taken from the Swadesh's list ${ }^{2}$ and 10 from the supplemental list of Jakhontov ${ }^{3}$ there are 99 units which are common for Beserman idiom and Udmurt language. For these reasons, we treat Beserman as a dialect of Udmurt.

The question of Beserman ethnogenesis is still discussed and is far from getting any satisfactory answer. For different hypotheses see Napolskikh (1997), Teplyashina (1970),

\footnotetext{
${ }^{2}$ The Swadesh's list (see Kassian, Starostin, Dybo \& Chernov 2010) represents 100 most stable items of the basic vocabulary of human languages. After certain modifications, it has become a very important tool of comparative linguistics.

${ }^{3}$ S. Yakhontov has offered a modified version of Swadesh's list and divided it into the most stable part (35 words) and the part that is lost more quickly (65 words). A common praxis of lexicostatistical studies now is to combine the Swadesh's list of 100 words with the following 10 cognates offered by Yakhontov: far, heavy, near, salt, short, snake, thin, wind, worm, year. For the reasons and details see Burlak \& Starostin (2005: 12-13).
} 
Nasipov (2010). But it is indisputable that the history of the ethnic group is rich in contacts with speakers of different languages from several language families. Some of these languages - primarily Tatar, Udmurt and Russian - still keep their important role in formation of the idiom in question. Here we will focus on the influence which Russian exerts on oral speech of Beserman speakers living in Shamardan (Yukamenskoye district, Udmurtia, Russian Federation).

All Beserman speakers living in Shamardan are multilingual. They speak at least Beserman dialect which they strictly separate from Udmurt literary language, Udmurt and Russian. Beserman is the means of every-day communication. Udmurt is acquired at primary school. It is used while reading school textbooks and regional newspapers and in talks with Udmurt neighbors from the same village. Russian is learned at school. It is the official language of the country, i.e. the language of all situations except every-day communication: it is used to speak with officials, teachers at secondary school, while watching TV, reading most newspapers and books etc. Being the main means of communication in most situations, Russian has a great influence on the speech of Beserman people. The easiest way to analyze this influence is to look at a corpus of texts which contains transcriptions of Beserman oral speech. To make such analysis is the main aim of this paper.

It should be noted that the problem of the influence of Russian on Udmurt has already attracted the researchers' attention. Different aspects of it from Udmurt-Russian code-switching and code-mixing to adoption of Russian grammatical features in Udmurt have been studied. For the most recent results in this field see, for example, Solomennikova (2012), Shirobokova (2011), Kaysina (2013). However, as far as we know, the Beserman dialect has not been taken into account from this point of view yet.

We start by defining the object of our study. We investigate the influence of Russian on Beserman by analyzing the cases of code-mixing and recent lexical borrowing. The terminus "code-mixing" is used here in the same sense as in Muysken (2000) referring to cases when lexical items, grammatical (and, as we must add, phonetical) features of several languages are used in one utterance. Examples of code-switching, i.e. "the rapid succession of several languages in a single speech event" (Muysken 2000: 1), as in (1), also appear in our corpus of Beserman texts: 
(1) Beserman Udmurt fieldnotes:

\begin{tabular}{|c|c|c|c|c|c|c|c|c|c|}
\hline Bakč’a-ja-z & sâl-e. & Vot & vo & sâl-e & & sâl-e, & & $\underline{a}$ & ja \\
\hline kitchen.garden-Loc-P.3 & stand-Prs.3Sg & $\mathrm{DM}_{\text {rus }}$ & $\mathrm{DM}_{\text {rus }}$ & stan & s.3Sg & stand & s.3Sg & Conj $_{\text {rus }}$ & me $_{\text {rus }}$ \\
\hline uma-I-a & ani-je! & Malpa-j & & $n^{\prime} i$ & urt-a-z & & pə̂r-i-z & & uวิ \\
\hline$t-3 S_{\text {rus }}$ now rus & DM mothe & 1 think.Ps & & now & house-II & I.-P.3 & enter & st-3 & Conj \\
\hline
\end{tabular}

She is in the kitchen garden, here, here she is, and I was sure that she was there, she was, oh, my gosh! I was sure, that she had entered the house (underlined fragment of the sentence is in Russian).

Such cases are beyond the scope of this article, but we would like to notice that examples of code-switching from our corpus seem not to be motivated by any external factors like change of the speech situation, of the addressee etc. So, the situation with Beserman, Russian and Udmurt, at least in Shamardan, is not that of "ideal multilinguism" (Weinreich 1963). But nevertheless the language competence of the speakers elder than 25 years old seems to be very good: they speak with each other fluently, the cases of switching to Russian are relatively rare and the length of Russian fragments of discourse normally does not exceed 1-2 sentences (at least in informal talks).

We must stress that we distinguish code-mixing from lexical borrowing. It is not a trivial task since there is a considerable amount of Beserman roots loaned from Russian. Thus, R. Idrisov (2013) shows that in the sample of 1912 non-derived Beserman roots $48 \%$ are common Permic, 14\% loaned from Turkic languages, 17\% loaned from Russian and $21 \%$ do not have reliable etymologies (Idrisov 2013). It is a common praxis to treat as borrowed words those which are included in normative dictionaries of the investigated idioms (for Udmurt this strategy was used in, for example, Solomennikova (2012)). But the on-line dictionary of the Beserman dialect (http://beserman.ru) is still under elaboration. So we treat as loanwords those lexical units which are phonetically and morphologically adopted. All the other cases when Russian words appear in our corpus we consider to be the cases of code-mixing. For example, the lexical unit petuk 'rooster' is loaned from Russian, but it was phonetically transformed according to Beserman phonetic rules, whereas petux 'rooster' is a Russian word with Russian phonetic structure 
(Beserman system of consonants does not include the sound [x] (Idrisov 2013: 33-34)), so its appearance in a Beserman text is a case of code-mixing.

As for grammar features, we also (along with code-mixing) take into account the cases of loaning a Russian grammatical unit in order to cover a gap in Beserman system.

After defining the object of our investigation let us describe the corpus of texts we used. We shall try to show how the Russian influence is manifested in 19 texts (about 2,5 hours of oral speech) recorded and transcribed in Shamardan in January and July 2010. The texts were collected during experiments concerning conditions of the choice between local cases and postpositions for expressing spatial relations. There are three groups of texts corresponding with the tree types of experiments: 10 monologues describing the events developing in a 4-minute cartoon; 6 dialogues where the main speaker explains the second speaker how to place cards on a picture; 3 dialogues containing explanations how to move three figures through a model of the Shamardan area.

Cartoons, cards, figures, locations and roots were identical for all the speakers. The texts were recorded from 11 speakers ( 6 men and 5 women). Two speakers were young women between 25 and 30 years old, the rest were elder than 60 . The reason is that there are only a few Besermans under 30 living in Shamardan permanently (it is a pity because young Besermans in general speak quite fluently). As for children, they do not acquire Beserman as a mother tongue being able only to understand Beserman oral speech and using some words. In the given 19 texts Russian influence can be retraced at practically all the levels of the idiom: phonetics, morphology, vocabulary, syntax, and discourse.

\section{Phonetics}

In Beserman there is a strong tendency to conform to the Beserman phonetic rules in speech. But nevertheless the Russian influence exists even at this level. We will illustrate it with two examples. 
First, as mentioned before, in Beserman system there is no sound [x], but it may occur in Russian words used in fluent speech instead of phonetically adopted Beserman ones:

(2) Beserman Udmurt fieldnotes:

Kwin', n'ul', vit'-et'i-jez petux.

three four five-Ord-P.3 rooster $_{\text {rus }}$

[counting the figures] Three, four, and the fifth is a rooster.

Such pronunciation of the word denoting 'rooster' is treated by the native speakers we have worked with as being Russian (not Beserman). In their judgment, the Beserman word for 'rooster' is [petuk], as in (3):

(3) Beserman Udmurt fieldnotes:

$\begin{array}{llllllll}\text { Petuk } & \text { no } & \text { kureg } & \text { no } & \text { soos } & \text { mân-o } & \text { vič’ak } & \text { š'iškồ-nâ. } \\ \text { rooster }_{\text {rus }} & \text { and } & \text { hen } & \text { and } & \text { they } & \text { go-Prs.3PI } & \text { everybody } & \text { eat-Inf }\end{array}$

The rooster and the hens, everybody is going for eating.

Second, there is also influence in suprasegmental domain. Udmurt stress is fixed on the final syllable of the word. N. Ljukina mentions that Russian words are often loaned in Beserman with conserving of Russian stress (Ljukina 2007: 134). According to our data, there is a tendency (at least in Shamardan) to pronounce loanwords with Beserman stress. But in fluent speech some Russian words with Russian stress may occur, though not very often. Compare:

(4) Beserman Udmurt fieldnotes:

$\begin{array}{llllllll}\text { Tatân... tat'jân } & \text { ik } & \text { pič'i } & \text { pi-len } & \text { kol'aska-jez, } & \text { pič'i } & \text { veloš'iped-ez. } \\ \text { here here } & \text { [correct: tatân] } & \text { DM } & \text { little } & \text { boy-Gen1 } & \text { pram }_{\text {rus }}-\text { P.3 } & \text { little } & \text { bicycle } \text { rus }-P .3\end{array}$

There is a pram of a little boy, a little bicycle here. 


\section{Morphology}

From now on we will take into account two phenomena on each language level examined - code-mixing and borrowing.

\subsection{Code-mixing}

In our corpus occur the following cases of using Russian morphological tools instead of Beserman ones. Thus, instead of Beserman inchoative construction "kuč'kânâ 'to start' + infinitive" appears the Russian construction "davaj 'let' + infinitive":

(5) Beserman Udmurt fieldnotes:

$\begin{array}{llll}\text { I } & \text { davaj } & \text { až'-lan' } & \text { mânə̃-nวิ. } \\ \text { and } & \text { Inch }_{\text {rus }} & \text { forward-All } & \text { go-Inf }\end{array}$

And they began to go forward.

Constructions with inchoative meaning also represent a very interesting type of code-mixing which appears in our corpus several times involving different morphological units. Namely, Russian means of expressing a grammatical meaning is sometimes used together with (or contaminated with) its Beserman analogue. In such cases the meaning is actually expressed two times by morphological units from different idioms. Example (6) represents this peculiar "double-marking" of inchoative meaning, examples (9) and (10) below - of optative and debitative meanings correspondingly. "Double-marking" appears to be the most common strategy of borrowing which can be found on all language levels except phonetics (more examples will be presented later).

(6) Beserman Udmurt fieldnotes:

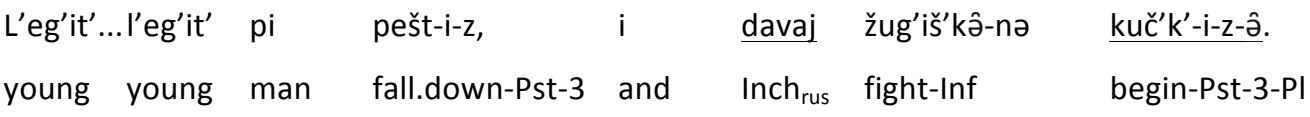

The young man fell down, and (they) began to fight. 
There are also cases of using a Russian negation marker instead of a Beserman one:

(7) Beserman Udmurt fieldnotes:

$\begin{array}{lll}\text { Petuk } & \underline{\mathrm{n}^{\prime} \mathrm{e}} & \text { so. } \\ \text { rooster }_{\text {rus }} & \mathrm{Neg}_{\text {rus }} & \text { this }\end{array}$

This is not a rooster.

This case of morphological code-mixing occurs in the corpus occasionally. The speakers strongly tend to use the Beserman marker. Example (8) belongs to the same speaker as (7), and it appeared in the same dialog:

(8) Beserman Udmurt fieldnotes:

$\begin{array}{lll}\text { Evâl } & \text { eta } & \text { petux. } \\ \text { Neg } & \text { this }_{\text {rus }} & \text { rooster } \\ \text { rus }\end{array}$

This is not a rooster.

Next, optative can be expressed through contamination of Beserman and Russian morphological tools:

(9) Beserman Udmurt fieldnotes:

\begin{tabular}{|c|c|c|c|c|c|c|c|c|c|}
\hline Mar & ke & otân... & aj, ol & 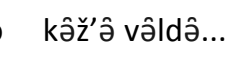 & ja & goroč’ka, & puskaj & med & lu-o-z... \\
\hline that & Cond & there & $\mathrm{DM}_{\text {rus }} \mathrm{O}$ & how DM & DM & little.hill & $\mathrm{OPT}_{\text {rus }}$ & OPT & be-Fut-3 \\
\hline & & tod-iš'k & & kâž’â & vera & & & & \\
\hline & & know-P & rs-Sg & how & tell- & & & & \\
\hline
\end{tabular}

There is something... auch, or as it is known... well, let it be a little hill, I don't know, how to put it.

Compare:

(9a) Russian:

$\begin{array}{ll}\text { Puskaj } & \text { bud'-et. } \\ \text { Opt } & \text { be.Fut-3Sg }\end{array}$

Let it be.

Example with "double-marking" of debitative meaning: 
Dialectologia 17 (2016), 123-150.

ISSN: 2013-2247

(10) Beserman Udmurt fieldnotes:

I van' tânad otân lu-o-z veloš'iped, vel'ik otân tânad dolžen lu-âno.

and is you.Gen1 there must.be-Fut-3 bicycle $_{\text {rus }}$ bike $_{\text {rus }}$ there you.Gen1 must rus $_{\text {must.be-Deb }}$

And you must have in there a bicycle, you must have a bike in there.

\subsection{Borrowing}

There are also several cases of loaning morphological units from Russian in order to cover the gaps in Beserman system. One of them is using the Russian word davaj to form imperative of the first person which does not exist in Beserman (Teplyashina 1970: 236):

(11) Beserman Udmurt fieldnotes:

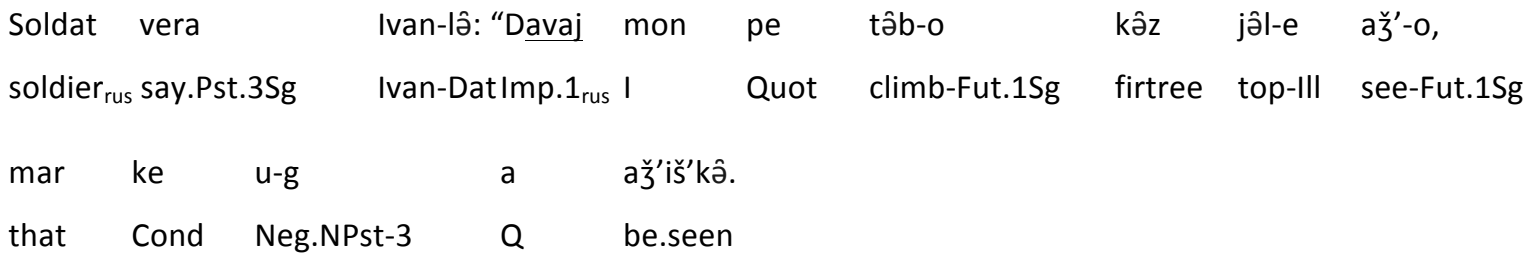

The soldier said to Ivan: "Let me climb the firtree top, maybe something is seen (from there)".

(12) Beserman Udmurt fieldnotes:

\begin{tabular}{|c|c|c|c|c|}
\hline Maša, & aš'mes & kuč'k-o-m & skal-jos & dor-iš'en. \\
\hline lasha & Imp.1 $1_{\text {rus }}$ Refl.1PI & start-Fut-1PI & cow-PI & neighbourhood-Egr \\
\hline
\end{tabular}

Masha, let us start with the cows.

The other case is the Russian word samoj which function in Beserman as superlative marker (in Beserman there is no other means to express this meaning) (Teplyashina 1970: 179):

(13) Beserman Udmurt fieldnotes:

$\begin{array}{ll}\text { samoj } & \text { umoj } \\ \text { Superlat }_{\text {rus }} & \text { good }\end{array}$

the best 
This marker can be joined also to words functioning as nouns:

(14) Beserman Udmurt fieldnotes:

$\begin{array}{llll}\text { Veloš'iped } & \text { wan' vâl-ân, } & \text { samoj } & \text { vâl-ân. } \\ \text { bicycle }_{\text {rus }} & \text { there.is top-Loc } & \text { Superlat }_{\text {rus }} & \text { top-Loc }\end{array}$

There is a bicycle above, at the top.

\section{Vocabulary}

\subsection{Code-mixing}

Such cases are relatively rare, but they do exist:

(15) Beserman Udmurt fieldnotes:

$\begin{array}{llllll}\text { Tabere } & \text { Paša } & \text { L'emskoj-ən } & \text { opet', korka }_{\text {ś'er-a-z, }} & \text { dal'n'ij korka š'er-a-z. } \\ \text { then } & \text { Pasha L'emskij-Loc } & \text { again }_{\text {rus }} \text { house } & \text { behind-Loc-P.3 } & \text { distant }_{\text {rushouse behind-Loc-P.3 }}\end{array}$

And then, Pasha is now in Lemskij (a settlement near Shamardan) again, behind the house, behind the distant house

(note that the Russian word dal'n'ij 'distant' is used instead of the Beserman widespread word kâd'okâšs' 'distant'; bold type indicates stress).

\subsection{Borrowing}

In our corpus of texts two cases of borrowing the vocabulary units occurred. In the first case, the new word is coming together with the new actual. With the lapse of some time, such words are phonetically and morphologically adopted:

(16) Beserman Udmurt fieldnotes:

$\begin{array}{llllll}\text { I } & \text { majeg } & \text { jâl-a-z } & \text { sâl-e } & \text { puktâ-mân } & \text { č’ôgân. } \\ \text { and } & \text { stake } & \text { top-Loc-P.3Sg } & \text { stand-Prs.3Sg } & \text { put-Res } & \text { cast-iron.pot }_{\text {rus }}\end{array}$

And somebody has put a cast-iron pot at the top of the stake, and now it is there

(in Russian the word denoting 'cast-iron pot' is pronounced as [chugun]). 
Dialectologia 17 (2016), 123-150.

ISSN: 2013-2247

(17) Beserman Udmurt fieldnotes:

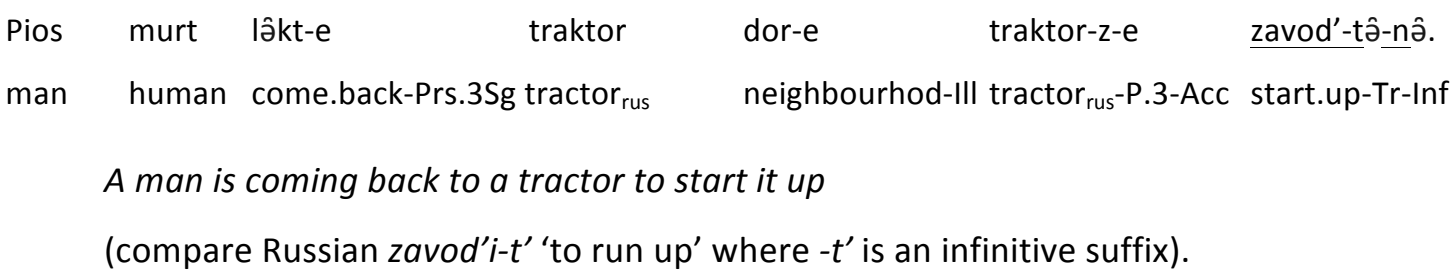

In the second case, the Russian word (chashja 'a thick forest' is a Slavic word, see Vasmer 1986-1987) replaces the Beserman one. In this case the word also can be phonetically (18) or/and morphologically (19) adopted:

(18) Beserman Udmurt fieldnotes:

$\begin{array}{llll}\text { Pič'i } & \text { pi } & \text { vel't'â-mân } & \text { č́ašja-je. } \\ \text { little } & \text { boy } & \text { walk-Res } & \text { forest-III }\end{array}$

Little boy went to the forest

(compare Russian chash'a 'a thick forest').

(19) Beserman Udmurt fieldnotes:

$\begin{array}{lllll}\text { Odig-âz } & \text { pâd-âz } & \text { gol'ik, } & \text { odig-âz } & \text { noski-jen. } \\ \text { one-P.3 } & \text { leg-P.3 } & \text { bare } & \text { one-P.3 } & \text { sock }\end{array}$

One leg is bare and the other is in the sock

(the Russian word noski is a plural form of a word nosok 'sock'; note also that there is an old Beserman word pâd nâr 'sock, socks').

It is a productive model in Beserman to adopt the frequent plural forms of Russian nouns as words denoting one object. Here are two more examples of this kind:

(20) Beserman Udmurt fieldnotes:

piroški-os

pie-PI

pies (The Russian word pirosh $k^{\prime} i$ is a plural form and already denotes many pies.) 
(21) Beserman Udmurt fieldnotes:

štan

trousers

one pair of trousers

(The Russian word shtany is pluralia tantum; in Beserman $-y$ is lost in Nominative, but it still occurs as $-i$ in the oblique stem of the noun.)

In the case of replacing a Beserman word through a Russian one also a semantic shift may occur. A good example is the word sad. In Russian it denotes a plot planted with trees, bushes and flowers or trees and bushes growing on such plot (Dal 1978). In Beserman this word has replaced the word č'ešpel' 'bushes, small young trees' and has acquired a meaning 'leaf-bearing tree' (having in this meaning also a plural form). (As far as we know, there is no Beserman word expressing the concept of a leaf-bearing tree - as there is no Beserman word denoting the coniferous tree).

Here we must say a few words about the difference among words belonging to different morphological classes with respect to the degree of adaptation. First of all, pronouns are never adopted. Numerals are adopted extremely seldom. Thus, we know only one numeral adopted from Russian - pervoj 'first'. For postpositions we also know only one case of substitution by a Russian word. Namely, the Beserman postposition mestaje (mesta-III) 'instead of' is a loan translation of the Russian preposition vm'esto ( $v$ mesto = in-place.Acc) 'instead of'. Adverbs are adopted rarely, and their degree of phonetic adaptation is close to that of nouns which may either be adopted (consider the word opet' 'again' in (15) which in Russian is pronounced as [op'at']; this word has completely substituted an old Beserman word nâš 'again') or not (22):

(22) Beserman Udmurt fieldnotes:

$\begin{array}{lll}\text { Obratno } & \text { tatč’ô } & \text { lâkt-i-z. } \\ \text { backwards }_{\text {rus }} & \text { here } & \text { return-Pst-3 }\end{array}$

[She] returned here, backwards

(Note that there is a widespread Beserman adverb berlan' 'backwards'.) 
Nouns are adopted most often, and they may be phonetically or/and semantically adopted or not (see (16) and (18) above). There are also cases of grammatical adaptation of nouns, most of them concerning the number of the noun (see (19)-(21) above).

Adjectives are often adopted, and they may also demonstrate phonetic and semantic shift or not (see (15) again).

Verbs are generally adopted without semantic shift but they are very good adopted phonetically. Furthermore, Beserman demonstrates two productive models of verbal adaptation. First, some verbs are adopted through taking the verbal stem (phonetically adopted, if necessary) and attaching Beserman inflexions - sometimes even derivational suffixes - to it. The second (and much more universal) strategy is to take the infinitive of the Russian verb and to attach the inflectional forms of the Beserman verb karânâ 'to do' to it. To use such a strategy is often the first reaction during the speech generation even if a good Beserman verbal equivalent exists. But while speaking to us Besermans often corrected themselves at once:

(23) Beserman Udmurt fieldnotes:

\begin{tabular}{|c|c|c|c|c|c|c|}
\hline Soldat & soje & opat' & spaš't'i & kar-e, & e, & jurt-[e] \\
\hline soldier & he.Acc & again $_{\text {rus }}$ & to.save $_{\text {rus }}$ & do-Prs.3Sg & Autocorr & save-[Prs.3Sg] \\
\hline e & jurt-e, & & n'e spasajet, & a & & \\
\hline eg $_{\text {rus }}$ & save-Pr & s.3Sg & [not saving] $]_{\text {rus }}$ & but & $.3 \mathrm{Sg}$ & \\
\hline
\end{tabular}

The soldier again saves him...no, saves, not "spasajet" but "jurte".

Conjunctions are adopted very actively replacing the Beserman ones. In general they are adopted neither phonetically nor functionally. Compare:

(24) Beserman Udmurt fieldnotes:

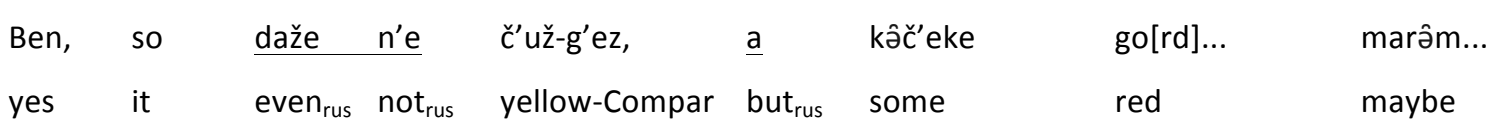

Yes, it is even not yellow but red or the like... maybe... 
Finally, during the borrowing of words the "double marking" of sense may occur. Thus, a Russian word expressing a concept may occur together with a Beserman one which has the concept in its semantic structure as a component. Compare:

(25) Beserman Udmurt fieldnotes:

$\begin{array}{llll}\text { Mânam } & \text { even' } & \text { bol'she } & \text { kureg-jos-ô. } \\ \text { I.Gen1 } & \text { have.no.anymore } & \text { more } & \end{array}$

I have no hens anymore.

It is notable that the order can be reversed (in Beserman there is a very small amount of expressions where the order of constituents can be reversed most of them being onomatopoetic ones):

(26) Beserman Udmurt fieldnotes:

bol'she even'

more $_{\text {rus }} \quad$ is.not.anymore

Not anymore.

Thus, the following hierarchy of susceptibility of different morphological classes to borrowing can be built for Beserman dialect:

conjunctions $<$ nouns $<$ verbs $<$ adjectives $<$ adverbs $<$ postpositions $<$ numerals $<$ pronouns.

In the case of susceptibility to borrowing Beserman is a very typical idiom. A close hierarchy (perhaps more detailed) can be drawn from (Matras 2009: 166-208).

\section{Syntax}

\subsection{Code-mixing}

According to our corpus, Russian influence on Beserman syntax was not at all as huge as on the vocabulary. There is a large amount of Beserman constructions which in 
our corpus (and according to our experience) are never replaced with Russian ones. One of them, for example, is a construction "finite verb + mân-participle" which has a resultative meaning (see (16)). But nevertheless there are some cases where Beserman constructions can be replaced by Russian ones. The first of them is the construction with sentential actants:

(27) Beserman Udmurt fieldnotes:

\begin{tabular}{|c|c|c|c|c|c|c|c|c|}
\hline$A \breve{s}^{\prime}-i-z$ & što & nâl & murt & šud-e & odig-ez & petux-ez & evâl, & pič'i \\
\hline see-Pst-3 & Conj $_{\text {rus }}$ & girl & human & feed-Prs.3Sg & one-P.3 & rooster $_{\text {rus }}-$ P. 3 & not & little \\
\hline etux & punna & & mân-i-z & biž'- & & & & \\
\hline oster rus $_{\text {rus }}$ & for & & go-Pst-3 & run- & & & & \\
\hline
\end{tabular}

He saw that the girl was feeding [birds] and that one chicken was missing, and the boy ran for the chicken.

\section{Compare:}

(27a) Russian:

$\begin{array}{lllll}\text { Uv'id'e-I- } \varnothing & \text { što } & \text { d'evuška } & \text { korm'-it } & \text { kur- } \varnothing . \\ \text { see-Pst-M.Sg } & \text { Conj } & \text { girl } & \text { feed-Prs.3.Sg } & \text { hen-Gen.PI }\end{array}$

He saw that a girl was feeding hens.

(27b) illustrates the common Beserman construction with the verb až'ẑnâ 'to see':

(27b) Beserman Udmurt fieldnotes:

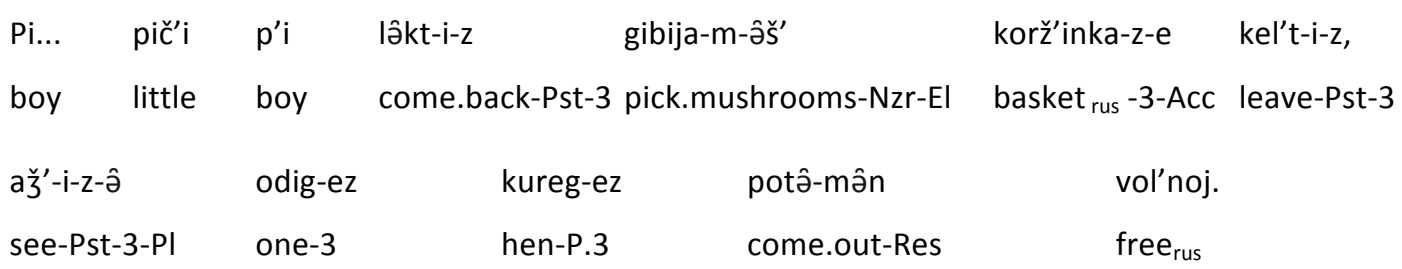

The little boy came back from picking mushrooms, left his basket and saw that a hen had come out, [and now it is] free.

The second construction is the comparative one: 
(28) Beserman Udmurt fieldnotes:

$\begin{array}{lllllll}\text { So } & \text { kak budto } & \text { š'aš'eg } & \text { pi-jez-lâš' } & \text { bâž-z-e } & \text { kurč'-e } & \text { n'i. } \\ \text { he } & \text { Compar rus }^{\prime} & \text { goose } & \text { son-P.3-Gen2 } & \text { tail-P.3-Acc } & \text { bite-Prs.3Sg } & \text { Emph }\end{array}$

It seems that he is biting the gosling's tail.

There are several types of Beserman comparative constructions. The most universal of them is the construction with kad' 'like':

(29) Beserman Udmurt fieldnotes:

Ben, ulla pal-a-z kad'.

yes lower side-Loc-P.3 like

Yes, it seems to be a bit lower.

Russian and Beserman comparative words can be used together forming a construction with "double marking":

(29a) Beserman Udmurt fieldnotes:

$\begin{array}{llllllll}\text { So } & \text { tin' } & \text { pânå } & \text { pi-jen } & \text { tuš'-en } & \text { visk-ân } & \text { kad' } & \text { kak by. } \\ \text { it } & \text { well } & \text { dog } & \text { son-Instr/Comit } & \text { trough-Instr/Comit between.Obl-Loc } & \text { like } & \text { like rus }\end{array}$

Well, it seems to be between a puppy and a trough.

It should also be noted that sometimes (hardly ever) the Russian verb frame is used together with the borrowed verb itself:

(30) Beserman Udmurt fieldnotes:

$\begin{array}{lllll}\text { Tak, fs'o, } & \text { razobra-l'-i-s's } & \text { kureg-jos-ân, } & \text { ben } & \text { a? } \\ \text { well } & \text { rus } & \text { that's.all } & & \text { deal-Pst-PI-Refl } \\ \text { rus } & \text { hen-PI-Instr/Comit } & \text { yes } & Q\end{array}$

Well, that's all, we have finished with the hens, haven't we?

Compare: 
Dialectologia 17 (2016), 123-150.

ISSN: 2013-2247

(30a) Russian:

$\begin{array}{lll}\text { Razobra-l'-i-s' } & \text { s } & \text { kur-am'i. } \\ \text { deal-Pst-PI-Refl } & \text { with } & \text { hen-Instr.PI }\end{array}$

We have finished with the hens.

The third construction is the coordinative one. The Beserman coordinative constructions with conjunction no...no 'and' (31) is often replaced with the Russian one with conjunction $i$ 'and' (32):

(31) Beserman Udmurt fieldnotes:

$\begin{array}{lllllll}\text { Ad'ami-z-e } & \text { no } & \text { kut-i-z } & \text { no } & \text { vu } & \text { pušk-â } & \text { dong-i-z. } \\ \text { man-P.3-Acc } & \text { and } & \text { catch-Pst-3 } & \text { and } & \text { water } & \text { in.Obl-III } & \text { push-Pst-3 }\end{array}$

[He] caught the man and pushed [him] into the water.

(32) Beserman Udmurt fieldnotes:

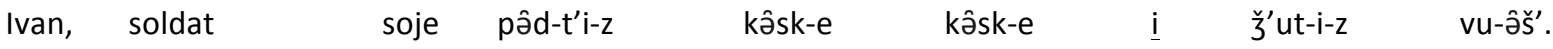

Ivan soldier $_{\text {rus }} \quad$ he.Acc leg-Prolat-P.3 draw-Prs.3Sg draw-Prs.3Sg and rus $_{\text {pull.out-Pst-3 water-EI }}$

(As for) Ivan, soldier is drawing and drawing (him) by his legs and pulled out of the water.

The Russian construction occurs much more often than the Beserman one. Besides, the "double marking" may also occur here:

(33) Beserman Udmurt fieldnotes:

L'eg'it' pi-z-e no miš'k-e i jâ...jə̂rč’ô-t'i-z kutว̂-sa vu-e donga.

young man-P.3-Acc and wash-Prs.3Sg and ${ }_{\text {rus }}$ hair-Prolat-P.3 catch-Conv water-III push.Pst.3

[He] washes the young man and after catching [him] by his hair pushes [him] into the water. 


\section{Discourse}

\subsection{Code-mixing}

In use of discourse markers (DM) the general tendency of combining the Russian and the Beserman variants ("double-marking") can be seen again:

(34) Beserman Udmurt fieldnotes:

$\begin{array}{lllll}\text { Ja } & \text { ladno, } & \text { pun-i-d } & \text { ke } & \text { pun-i-d. } \\ \text { well } & \text { well }_{\text {rus }} & \text { put-Pst-2 } & \text { Cond } & \text { put-Pst-2 }\end{array}$

Ok, if you have put [it] than you have put [it].

Another strategy is to replace one of the components of a complex Russian DM with a Beserman equivalent of this component:

(35) Beserman Udmurt fieldnotes:

$\begin{array}{ll}\mathrm{Nu} & \text { ten'. } \\ \text { well } & \text { here }\end{array}$

Well, we've finished.

Beserman ten' 'here' corresponds to Russian vot 'here', and nu ten' in (35) is used just as Russian marker nu vot.

\subsection{Borrowing}

Russian DMs can be also borrowed directly: ${ }^{4}$

(36) Beserman Udmurt fieldnotes:

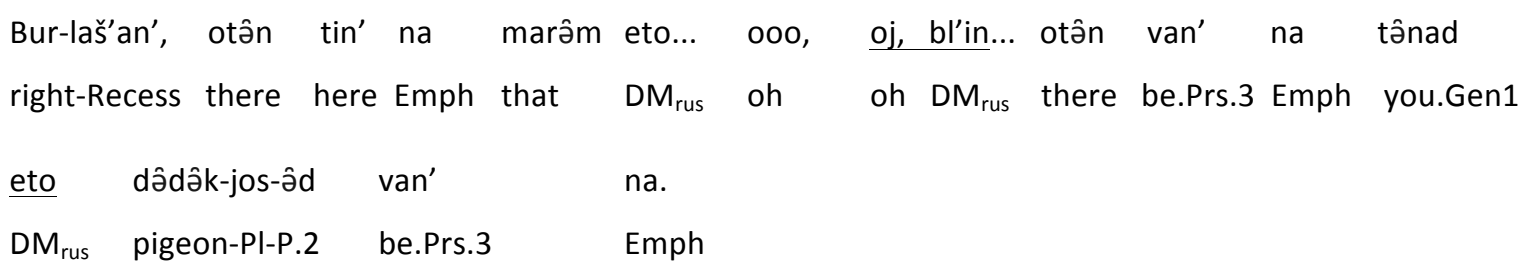

\footnotetext{
${ }^{4}$ Note that in a close-related Komi there is also a good amount of discourse words borrowed from Russian (Leinonen 2014).
} 
From the right side, there is... hm, oh, oh, damn, there is you have... eee... there are pigeons (underlined markers are adopted from Russian).

All the DMs appeared in our corpus are presented in Table 3 and Table 4 (see Appendix). In Table 3 for each DM the following information is given: a) its function in the discourse; b) its origin (Russian, Beserman, Russian-Beserman (mixed) or unknown); c) its phonetic form; d) number of occurrences in the corpus; e) number of speakers which have used it. The number of speakers and the number of occurrences decreases from the top of the table to its bottom. Note that the functions of the markers are labeled very roughly. The studying of Beserman DM is only at an initial stage, so we can in no case pretend to present a complete analysis of them. The functional labels are given there just for illustrative purposes.

Table 4 demonstrates the correspondence between Beserman markers and their supposed Russian analogues. Again, for each marker the origin (Beserman or Russian), the function, the phonetic form, number of occurrences in the corpus and number of speakers which have used it are given.

The data given in the Appendix are summarized in Table 1:

\begin{tabular}{|l|l|l|l|l|}
\hline \multirow{2}{*}{ Origin } & \multicolumn{3}{|c|}{ Degree of generality } \\
\cline { 2 - 5 } & $\begin{array}{l}\text { The most frequent (5- } \\
10 \text { speakers) }\end{array}$ & $\begin{array}{c}\text { Less frequent (2-4 } \\
\text { speakers) }\end{array}$ & Rare (1 speaker) & All \\
\hline Russian & 11 & 18 & 34 & 63 \\
\hline Beserman & 17 & 10 & 8 & 35 \\
\hline Mixed ("double-marking") & 0 & 4 & 0 & 21 \\
\hline Unknown & 2 & 11 & 8 & 4 \\
\hline
\end{tabular}

Table 1. The distribution of DM of different origin used in Beserman dialogs according to their degree of generality

Here the "degree of generality" means number of speakers who used DMs of given origin. DMs which appeared as a result of the "double-marking" strategy are labeled as "mixed". Calques from Russian are concerned to have Russian origin. 
One can see from Table 1 that the amount of DMs which are supposed to be borrowed from Russian tend to increase with the decreasing of the amount of people using it. Roughly speaking, we can say that Russian DMs tend to be individual (except nu which has practically substituted the corresponding Beserman marker ma). The amount of markers with Beserman origin, on the contrary, tend to decrease with the decreasing of the amount of speakers - roughly speaking, they tend to be more common. On the other hand, the total amount of Russian DMs significantly exceeds the total amount of Beserman ones (63 vs 35 respectively). The entire situation looks like that the influence of Russian on Beserman has significantly grown recently: different speakers have acquired different DMs which have not stabilized yet in the language praxis of the community. DMs and connectors are claimed to be the group which is borrowed more quickly than other grammatical function words (Matras 2009) and than many other common linguistic items (Leinonen 2014), so the beginning of the active borrowing of them seems to be a good criterion of a new wave of significant influence from an external idiom.

\section{Conclusions}

Results of the analysis presented in this paper are summarized in Table 2:

\begin{tabular}{|c|c|c|c|c|c|}
\hline \multirow{2}{*}{$\begin{array}{l}\text { Type of } \\
\text { influence }\end{array}$} & \multicolumn{5}{|c|}{ Language level } \\
\hline & Phonetics & Morphology & Vocabulary & Syntax & Discourse (DMs) \\
\hline Code-mixing & $\begin{array}{l}\text { Words with } \\
\text { Russian phonetic } \\
\text { structure and/or } \\
\text { Russian stress }\end{array}$ & $\begin{array}{l}\text { Inchoative } \\
\text { Optative } \\
\text { Debitative } \\
\text { Negation }\end{array}$ & Rare & $\begin{array}{l}\text { Comparative } \\
\text { constructions } \\
\text { Constructions with } \\
\text { the sentential } \\
\text { actants } \\
\text { Coordinative } \\
\text { construction }\end{array}$ & Not very often \\
\hline Borrowing & ------------ & $\begin{array}{l}\text { Imperative of } \\
\text { the } 1^{\text {st }} \text { person } \\
\text { Superlative }\end{array}$ & $\begin{array}{l}\text { conjunctions < } \\
\text { nouns }<\text { verbs }< \\
\text { adjectives < } \\
\text { adverbs }< \\
\text { postpositions < } \\
\text { numerals }< \\
\text { pronouns }\end{array}$ & $\begin{array}{l}\text { Valency patterns } \\
\text { (extremely rare) }\end{array}$ & Very often \\
\hline
\end{tabular}

Table 2. Russian influence on Beserman Udmurt on different language levels 
Observing all cases of Beserman-Russian code-mixing and of borrowing from Russian into Beserman which are presented in our corpus of texts we can see that the degree of influence is not as great as it might seem to be. A really great amount of units borrowed from Russian essentially appears only among nouns, but such loanwords tend to be phonetically, morphologically and even semantically adopted. Loanwords belonging to other parts of speech either occur seldom or are phonologically adopted. As for morphology, there are not many tools borrowed, most of them fulfilling the gaps in the Beserman system. The most frequent discourse markers in general have Beserman origin. The syntax practically has not been influenced by Russian. In the discourse of 25-30 years old speakers there are more adopted constructions and morphological borrowed units than in the discourse of 60-85 year old people, but the disparity is not very big. A possible reason is that young Besermans use their mother tongue while talking to each other and to their relatives.

The degree and peculiar properties of Russian influence on Beserman dialect lead to the suggestion that in more favorable sociolinguistic situation the result could be a mixed idiom with predominantly Russian vocabulary and Beserman basis of grammar. The loaned language units are likely not to be copied without noticeable changes, but to be adopted, even in special strategies of borrowing ("karânâ 'to make' + infinitive", "double marking"). Examples of mixed languages are numerous (for one of the most recent of them, Gurundji Kriol, which arose in the 1970s- 80s, see McConvell \& Meakins 2005). Mixing with other idioms (or, in other terms, copying vocabulary units and grammar features of them (Johanson 2002) seems to be a normal phenomenon in a language's life. Linguists have even started to take it into account while building family trees of languages (McMahon \& McMahon 2006). But Beserman dialect unfortunately has no chance to reach this stage. It is supposed to die in recent years because people under 25 do not speak Beserman. All the grandchildren and little children of people we worked with in Shamardan do not speak Beserman. Most of them even do not understand Beserman speech. The idiom is also not taught at school. Thus, Beserman Udmurt seems to be a sad example confirming Lars Johanson's statement that codes never die of structural changes 
of any kind, they "die because they are no longer acquired by the new generations" (Johanson 2002: 267).

\section{References}

BURLAK, Svetlana A. \& Sergey A. STAROSTIN (2005) Sravnitelno-istoricheskoye yazykoznaniye [Comparative Linguistics], 2nd edition, Moscow: Akademiya.

DAL, Vladimir I. (1978) [Tolkovyj slovar zhivogo velikorusskogo jazyka], v. 1-4, Moskva.

IDRISOV, Ruslan I. (2013) Turkish Loanwords of Different Periods in Beserman Udmurt [Tjurkskije zaimstvovanija raznykh periodov $v$ besermianskom dialekte udmurtskogo jazyka], Thesis, Moscow, Manuscript.

JOHANSON, Lars (2002) “Do languages die of 'structuritis'? On the role of code-copying in language endangerment", Rivista di Linguistica, 14(2), 249-270.

KAYSINA, Inna (2013) "The adoption of Russian Conjunctions in Udmurt", ESUKA-JEFUL 2013, 4-2, 131-144.

KASSIAN, Alexei, George StAROStin, Anna Dybo \& Vasiliy Chernov (2010) "The Swadesh wordlist. An attempt at semantic specification", Journal of Language Relationship, 4, 46-89.

KELMAKOV, Valej K. (1998) "A brief sketch of Udmurt dialectology. Introduction. Phonetics. Morphology. Texts on Udmurt dialects. References" [Kratkij kurs udmurtskoj dialektologii. Vvedenije. Fonetika. Morfologija. Dialektnyje teksty. Bibliografija], Izhevsk: Udmurt State University.

LEINONEN, Marja (2014) "Borrowability of function and discourse words: the Komi case", Language Contacts: the State of the Art, Helsinki, August 28-30, 2014, Report.

LJUKINA, Nadezhda M. (2007) "Word Stress in Beserman Patois of Udmurt [Slovesnoje udarenije v besermianskikh govorakh udmurtskogo jazyka]", Current Problems of Science and Education [Sovremennyje problemy nauki i obrazovanija], 6, Moscow: Akademija obrazovanija, 132135.

LJUKINA, Nadezhda M. (2008) The peculiarities of the language of Balezino and Jukamenskoje Besermans, PhD-thesis. [Osobennosti jazyka balezinskikh i jukamenskikh besermian.] Moscow, Manuscript.

MATRAS, Yaron (2009) Language Contact, Cambridge: Cambridge University Press.

McConvelL, Patrick \& Felicity MeakIns (2005) "Gurindji Kriol: A Mixed Language Emerges from Code-switching", Australian Journal of Linguistics, 25(1), 9-30. 
MCMAHON, April \& Robert MCMAHON (2006) "Keeping Contact in the Family: Approaches to Language Classification and Contact-induced Change", in Yaron Matras et al. (eds.), Linguistic Areas. Convergence in Historical and Typological Perspective, Houndmills: Palgrave Macmillan, 51-74.

MUYSKEN, Pieter (2000) Bilingual Speech: A Typology of Code-Mixing, Cambridge: Cambridge University Press.

NAPOLSKIKH, Vladimir V. (1997) Introduction to Historical Uralistics [Vvedenije v istoricheskuju uralistiku], Izhevsk: Udmurt Institute of History, Language and Literature, Ural Branch of Russian Academy of Sciences Publ.

NASIPOV, Ilshat S. (2010) Finno-Ugric Loanwords in Tatar: Synopsis and Taxonomy [Finno-ugorskije zaimstvovanija $v$ tatarskom jazyke: sinopsis i taksonomija], Doctoral thesis, Kazan, Manuscript.

SHIROBOKOVA, Larisa (2011) Udmurt-Russian Bilingualism (Udmurt Republic, Sarkan Region, Muvyr Village), PhD-dissertation, Budapest, Manuscript.

Solomennikova, Anastasija P. (2012) "Code-switching and Code-mixing in the Udmurt Speech of Udmurt-Russian Bilinguals (fieldwork experiment)" [Perekljuchenije i smeshenije koda v rechi udmurtsko-russkikh bilingvov (opyt polevogo issledovanija)], The Questions of Philology [Voprosy filologii], 3 (42), 89-98.

TEPLYASHINA, Tamara I. (1970) The Language of Beserman [Jazyk Besermian], Moscow: Nauka.

VASMER, Max (1986-1987) Russian Etimological Dictionary [Etimologicheskij slovarj russkogo jazyka], 4 volumes, Moscow: Progress.

WeINREICH, Uriel (1963) Languages in Contact: Findings and Problems, $2^{\text {nd }}$ edition, The Hague: Mouton. 


\section{Appendix}

\section{Frequency of DMs in the corpus}

\begin{tabular}{|c|c|c|c|c|}
\hline function & $\begin{array}{c}\text { Beserman / } \\
\text { Russian }\end{array}$ & marker & $\begin{array}{c}\text { corpus } \\
\text { frequency }\end{array}$ & $\begin{array}{c}\text { number of } \\
\text { speakers }\end{array}$ \\
\hline emphasis & bes & $n^{\prime} i$ & 182 & 10 \\
\hline question & bes & $a$ & 162 & 10 \\
\hline emphasis & rus & nu & 113 & 10 \\
\hline emphasis & bes & na & 72 & 10 \\
\hline agreement & bes & ben & 264 & 9 \\
\hline emphasis & bes & uk & 95 & 8 \\
\hline end/beginning of the episode & rus & tak & 90 & 8 \\
\hline beginning of the new episode & rus & a & 76 & 8 \\
\hline request for attention & bes & $\mathrm{ik}$ & 59 & 8 \\
\hline $\begin{array}{l}\text { declining the speaker's } \\
\text { responsibility for the content } \\
\text { of the utterance }\end{array}$ & bes & mar a & 34 & 8 \\
\hline perplexity & rus & eto(t) & 21 & 8 \\
\hline change of topic & bes & sâre\so bere & 60 & 7 \\
\hline verification & bes & ben a & 49 & 7 \\
\hline $\begin{array}{l}\text { agreement against the wish of } \\
\text { the speaker }\end{array}$ & bes & $\mathrm{ja}$ & 37 & 7 \\
\hline understanding & rus & $a$ & 21 & 7 \\
\hline perplexity & rus & naverno & 14 & 7 \\
\hline autocorrection & bes & $\mathrm{e}$ & 11 & 7 \\
\hline agreement & rus & aha & 62 & 6 \\
\hline end of the episode & bes & $\operatorname{tin}^{\prime}$ & 45 & 6 \\
\hline emphasis & bes & ma & 18 & 6 \\
\hline request for some time & rus & 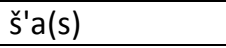 & 14 & 6 \\
\hline end of the episode & rus & fs'o & 13 & 6 \\
\hline agreement & $?$ & $\mathrm{mh}$ & 81 & 5 \\
\hline request for some time & bes & moga & 38 & 5 \\
\hline end of the episode & rus & vot & 36 & 5 \\
\hline quotation & bes & pe & 28 & 5 \\
\hline hesitation & $?$ & eeee & 25 & 5 \\
\hline $\begin{array}{l}\text { [yet failed to be determined } \\
\text { exactly] }\end{array}$ & rus & eššo & 19 & 5 \\
\hline negation & bes & evâl & 13 & 5 \\
\hline $\begin{array}{l}\text { declining the speaker's } \\
\text { responsibility for the content } \\
\text { of the utterance }\end{array}$ & bes & mar ke & 10 & 5 \\
\hline change of topic & bes & ta(be)re & 37 & 4 \\
\hline hesitation & rus/bes & marâm eto(t) & 33 & 4 \\
\hline $\begin{array}{l}\text { agreement against the wish of } \\
\text { the speaker }\end{array}$ & rus & ladno & 21 & 4 \\
\hline $\begin{array}{l}\text { declining the speaker's } \\
\text { responsibility for the content } \\
\text { of the utterance }\end{array}$ & bes & $\begin{array}{l}\text { marâm } \\
\text { (marâme) }\end{array}$ & 19 & 4 \\
\hline $\begin{array}{l}\text { [yet failed to be determined } \\
\text { exactly] }\end{array}$ & rus & tože & 15 & 4 \\
\hline hesitation & $?$ & $\mathrm{mmm}, \mathrm{emmm}$ & 14 & 4 \\
\hline
\end{tabular}


Dialectologia 17 (2016), 123-150.

ISSN: 2013-2247

\begin{tabular}{|c|c|c|c|c|}
\hline feedback & rus & a? & 11 & 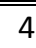 \\
\hline backchannel & rus & $\mathrm{a}$ & 10 & 4 \\
\hline agreement & rus & $\mathrm{da}$ & 10 & 4 \\
\hline beginning of the new episode & rus & $\mathrm{i}$ & 8 & 4 \\
\hline error report & $?$ & oj & 7 & 4 \\
\hline $\begin{array}{l}\text { agreement against the wish of } \\
\text { the speaker }\end{array}$ & rus/bes & ja ladno & 6 & 4 \\
\hline change of topic & rus & dal'še & 6 & 4 \\
\hline $\begin{array}{l}\text { [yet failed to be determined } \\
\text { exactly] }\end{array}$ & ?bes & no & 34 & 3 \\
\hline agreement & $?$ & $m-m$ & 12 & 3 \\
\hline verification & rus/bes & ben vet' & 10 & 3 \\
\hline $\begin{array}{l}\text { agreement against the wish of } \\
\text { the speaker }\end{array}$ & rus & puskaj & 8 & 3 \\
\hline perplexity & bes & leš'a & 7 & 3 \\
\hline $\begin{array}{l}\text { agreement against the wish of } \\
\text { the speaker }\end{array}$ & rus & nu ladno & 5 & 3 \\
\hline end of the episode & bes & ten' & 5 & 3 \\
\hline perplexity & $?$ & $\mathrm{a}$ & 4 & 3 \\
\hline $\begin{array}{l}\text { problems of speech } \\
\text { production }\end{array}$ & ? & oh & 3 & 3 \\
\hline perplexity & bes & vâldâ & 3 & 3 \\
\hline approximation & rus & poč't'i (što) & 19 & 2 \\
\hline verification & bes & valad-a & 7 & 2 \\
\hline disagreement & $?$ & $m-m$ & 7 & 2 \\
\hline surprise & $?$ & 0 & 5 & 2 \\
\hline perplexity & rus & možet & 5 & 2 \\
\hline hesitation & $?$ & $\mathrm{mh}$ & 5 & 2 \\
\hline hesitation & bes & $\hat{\partial}$ & 5 & 2 \\
\hline $\begin{array}{l}\text { declining the speaker's } \\
\text { responsibility for the content } \\
\text { of the utterance }\end{array}$ & rus & kak by & 4 & 2 \\
\hline word search & rus & $\mathrm{nu}$ & 4 & 2 \\
\hline autocorrection & $?$ & $\mathrm{fu}$ & 4 & 2 \\
\hline backchannel & bes & valaj & 3 & 2 \\
\hline $\begin{array}{l}\text { [yet failed to be determined } \\
\text { exactly] }\end{array}$ & rus & v obš'em (-to) & 3 & 2 \\
\hline request for some time & rus & sejčas & 2 & 2 \\
\hline recomposing & rus & koroč'e & 2 & 2 \\
\hline perplexity & $?$ & 0 & 2 & 2 \\
\hline error report & $?$ & aj & 2 & 2 \\
\hline end of the episode & rus/bes & nu ten' & 2 & 2 \\
\hline autocorrection & rus & to jest' & 2 & 2 \\
\hline $\begin{array}{l}\text { [yet failed to be determined } \\
\text { exactly] }\end{array}$ & bes & šu & 2 & 2 \\
\hline $\begin{array}{l}\text { [yet failed to be determined } \\
\text { exactly] }\end{array}$ & rus & vet' & 2 & 2 \\
\hline
\end{tabular}

Besides in our corpus of texts occur a lot of markers, which are used only by one speaker. They are: 
Beserman origin: mare, $\operatorname{tin}^{\prime} n^{\prime} a$ (tin' na), valamon, e, anije!, todiš'kod a, âzem, marâm $a$, ož' $a$.

Russian origin: tak vet', a, a č'o, a evâl, bl'in, e, n'et, fs'o ravno, gad, imenno, kak budto, kak raz, kon'ešno, n'et, nu puskaj, nu tin', nu vot, podi, podoždi, pogodi, pomojemu, primerno, razve, t'eper', t'ipa, tak-to, ten' tak, tol'ko, vern'eje, vet' tak vet', vidat', vo!, vrode, znač'it

Unknown origin: $e, h m, m, m-m, o, t^{\prime} f u, u h, u h m$. 
Dialectologia 17 (2016), 123-150.

ISSN: 2013-2247

\section{Amounts of DMs with different functions in the corpus}

\begin{tabular}{|c|c|c|c|c|c|c|c|c|c|c|c|c|}
\hline \multirow[t]{2}{*}{ function } & \multicolumn{3}{|c|}{ Beserman } & \multicolumn{3}{|c|}{ Russian } & \multicolumn{3}{|c|}{ mixed } & \multicolumn{3}{|c|}{ unknown } \\
\hline & 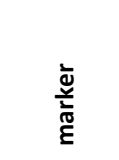 & 혼 & 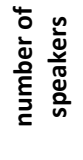 & 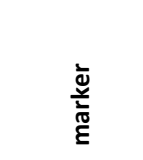 & 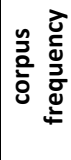 & 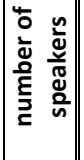 & 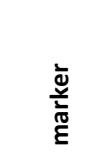 & 咅 & 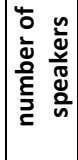 & 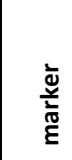 & 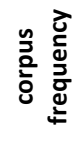 & 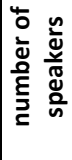 \\
\hline \multirow[t]{4}{*}{$\begin{array}{l}\text { agreement against the } \\
\text { wish of the speaker }\end{array}$} & ja & 37 & 7 & puskaj & 8 & 3 & \begin{tabular}{|l|} 
ja \\
ladno \\
\end{tabular} & 6 & 4 & & & \\
\hline & & & & nu puskaj & 1 & 1 & & & & & & \\
\hline & & & & nu ladno & 5 & 3 & & & & & & \\
\hline & & & & ladno & 21 & 4 & & & & & & \\
\hline TOTAL & & 37 & & & 35 & & & 6 & & & & \\
\hline \multirow{4}{*}{$\begin{array}{l}\text { declining the speaker's } \\
\text { responsibility for the } \\
\text { content of the utterance }\end{array}$} & marke & 10 & 5 & vrode & 2 & 1 & & & & & & \\
\hline & $\begin{array}{l}\text { marem } \\
\mathrm{a}\end{array}$ & 1 & 1 & kak by & 4 & 2 & & & & & & \\
\hline & $\begin{array}{l}\text { marəm } \\
\text { (marəm } \\
\text { e) }\end{array}$ & 19 & 4 & kak budto & 5 & 1 & & & & & & \\
\hline & mara & 34 & 8 & & & & & & & & & \\
\hline TOTAL & & 64 & & & 11 & & & & & & & \\
\hline \multirow[t]{5}{*}{ verification } & valad-a & 7 & 2 & $\begin{array}{l}\text { vet' tak } \\
\text { vet' }^{\prime}\end{array}$ & 1 & 1 & \begin{tabular}{|l|} 
ben \\
vet' \\
\end{tabular} & 10 & 3 & & & \\
\hline & $\begin{array}{l}\text { todiš'ko } \\
\mathrm{d} \text { a }\end{array}$ & 2 & 1 & tak vet' & 22 & 1 & & & & & & \\
\hline & ož' a & 1 & 1 & razve & 1 & 1 & & & & & & \\
\hline & əzem & 2 & 1 & & & & & & & & & \\
\hline & ben a & 49 & 7 & & & & & & & & & \\
\hline TOTAL & & 61 & & & 24 & & & 10 & & & & \\
\hline \multirow[t]{4}{*}{ request for some time } & moga & 38 & 5 & sejčas & 2 & 2 & & & & $\mathrm{~m}$ & 1 & 1 \\
\hline & & & & š'a(s) & 14 & 6 & & & & & & \\
\hline & & & & pogod'i & 1 & 1 & & & & & & \\
\hline & & & & podožd'i & 1 & 1 & & & & & & \\
\hline TOTAL & & 38 & & & 18 & & & & & & 1 & \\
\hline \multirow[t]{8}{*}{ perplexity } & vəldə & 3 & 3 & t'ipa & 1 & 1 & & & & 0 & 2 & 2 \\
\hline & leš'a & 7 & 3 & pod'i & 1 & 1 & & & & $a$ & 4 & 3 \\
\hline & & & & naverno & 14 & 7 & & & & & & \\
\hline & & & & n'et & 1 & 1 & & & & & & \\
\hline & & & & eto(t) & 21 & 8 & & & & & & \\
\hline & & & & a č'o & 1 & 1 & & & & & & \\
\hline & & & & vidat' & 1 & 1 & & & & & & \\
\hline & & & & možet & 5 & 2 & & & & & & \\
\hline TOTAL & & 10 & & & 45 & & & & & & 6 & \\
\hline \multirow[t]{3}{*}{ end of the episode } & tin' & 45 & 6 & vot & 36 & 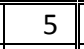 & nu tin' & 1 & 1 & & & \\
\hline & ten' & 5 & 3 & nu vot & 1 & 1 & \begin{tabular}{|l|} 
nu \\
ten' \\
\end{tabular} & 2 & 2 & & & \\
\hline & & & & fs'o & 13 & 6 & & & & & & \\
\hline TOTAL & & 50 & & & 50 & & & 3 & & & & \\
\hline \multirow[t]{4}{*}{ emphasis } & uk & 95 & 8 & $\mathrm{nu}$ & $\begin{array}{r}11 \\
3 \\
\end{array}$ & 10 & & & & & & \\
\hline & na & 72 & 10 & kak raz & 2 & 1 & & & & & & \\
\hline & $n^{\prime} i$ & 182 & 10 & imenno & 1 & 1 & & & & & & \\
\hline & $\mathrm{ma}$ & 18 & 6 & & & & & & & & & \\
\hline TOTAL & & 367 & & & \begin{tabular}{|c|}
11 \\
6 \\
\end{tabular} & & & & & & & \\
\hline
\end{tabular}




\begin{tabular}{|c|c|c|c|c|c|c|c|c|c|c|c|c|}
\hline \multirow[t]{2}{*}{ change of topic } & ta(be)re & 37 & 4 & t'eper' & 2 & 1 & & & & & & \\
\hline & 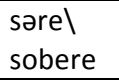 & 60 & 7 & dal'še & 6 & 4 & & & & & & \\
\hline TOTAL & & 97 & & & 8 & & & & & & & \\
\hline \multirow[t]{4}{*}{ autocorrection } & $\mathrm{e}$ & 11 & 7 & vern'eje & 2 & 1 & a evəl & 1 & 1 & $t^{\prime} f u$ & 1 & 1 \\
\hline & & & & to jest' & 2 & 2 & & & & $\mathrm{fu}$ & 4 & 2 \\
\hline & & & & n'et & 2 & 1 & & & & $\begin{array}{l}\mathrm{e}, \\
\text { n'et }\end{array}$ & 1 & 1 \\
\hline & & & & gad & 1 & 1 & & & & & & \\
\hline TOTAL & & 11 & & & 7 & & & 1 & & & 6 & \\
\hline \multirow[t]{5}{*}{ agreement } & ben & 264 & 9 & kon'ešno & 1 & 1 & & & & uhu & 1 & 1 \\
\hline & & & & $\mathrm{da}$ & 10 & 4 & & & & $\mathrm{~m}-\mathrm{m}$ & 12 & 3 \\
\hline & & & & aha & 62 & 6 & & & & $\mathrm{mh}$ & 81 & 5 \\
\hline & & & & & & & & & & $\mathrm{m}$ & 3 & 1 \\
\hline & & & & & & & & & & uhm & 1 & 1 \\
\hline TOTAL & & 264 & & & 73 & & & & & & 98 & \\
\hline
\end{tabular}

